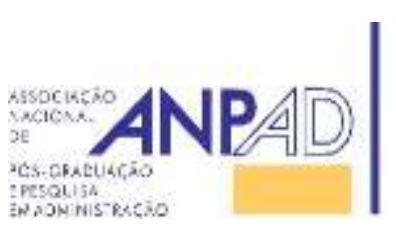

\author{
Available online at \\ http://www.anpad.org.br/bar \\ BAR, Rio de Janeiro, v. 13, n. 1, art. 4, \\ pp. 56-75, Jan./Mar. 2016 \\ http://dx.doi.org/10.1590/1807-7692bar2016150120 \\ (ल) $\mathrm{EY}$
}

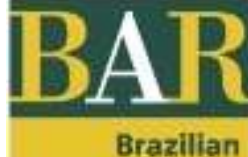

Administration Review

\title{
Analysis of Innovation and Its Environmental Impacts on the Chemical Industry
}

Dusan Schreiber $^{1}$

Uélinton Telmo Ermel ${ }^{1}$

João Alcione Sganderla Figueiredo ${ }^{1}$

Alexandre Zeni ${ }^{1}$

Universidade Feevale ${ }^{1}$

Received 21 May 2015; received in revised form in 7 March 2016 (this paper has been with the authors for three revisions); accepted in 8 March 2016; published online 28 April 2016. 


\begin{abstract}
Globalization of the economy and the need to achieve competitiveness drive organizations to invest in technology and in innovation, in order to find solutions that will provide advantages in an ever-more competitive market. The conflict between dwindling natural resources and the demand for economic growth has created a growing need to find means for making environmental conservation compatible with economic growth. The objective of this study is to contribute to the debate by analyzing the innovations implemented by chemical companies in the Sinos Valley region, Rio Grande do Sul, Brazil, and by identifying the motivations that drive them to develop environmental technologies. The study is exploratory and descriptive, with a quantitative data collection component in the form of a survey sent to all chemical companies in the Sinos Valley region, listed in a local business association database. The study results indicate that development of innovations is predominantly of an incremental nature and that novelty is generally restricted to the new-for-firm level. The environmental technologies implemented are generally designed to prevent or remedy environmental damage and are primarily motivated by the need to comply with environmental standards and legislation.
\end{abstract}

Key words: innovation; environment; environmental innovation. 


\section{Introduction}

Globalization of the economy and the need to be competitive have driven organizations to invest in technology and innovation, valuing quality, knowledge and competencies, in order to find solutions that can confer advantages in an ever-more competitive and globalized market. However, it has been observed that environmental concerns have remained as a secondary priority for organizations, which has led to demonstrable reductions in environmental quality. It is only recently (beginning in the second half of the 20th century), that the relationship between economic development and the environment has been approached from a new perspective, characterized by understanding of nature itself and of the existing resources and by the search for sustainable management of the resources for which each country has responsibility.

In this scenario, framed by concerns about environmental issues and the need for more competitive economic development, Porter and Van der Linde (1995) have pointed to the existence of synergies between competitiveness and environmental preservation. The central argument is that imposition of adequate environmental norms and standards will encourage companies to adopt innovations that reduce their costs or add value to their products and processes and which can make a contribution to the competitiveness of organizations (Porter \& Van Der Linde, 1995).

In light of this contextualization of innovation and environmental quality, this study presents an analysis on the process to introduce innovations by chemical companies in the Vale do Rio dos Sinos (hereafter the Sinos Valley), Rio Grande do Sul, Brazil, and motivations for developing environmental technologies. The study objective was to describe the characteristics of this specific process and to contribute to the debate, illustrating the importance of the subject and the necessity of confronting these issues in the Sinos Valley, in view of the region's development policies that privilege industrialization as the route to economic growth.

There is an as-yet incipient debate in Brazil about the determinant characteristics of firms that introduce innovation and about the consequences of this for their financial performance. Some Brazilian authors who have studied innovation in connection with the environment, such as PINTEC survey team (Andrade, 2004; Ferreira \& Kiperstok, 2007; Instituto Brasileiro de Geografia e Estatística [IBGE], 2010; Jaffe, Newell, \& Stavins, 2004), state that innovation is growing in Brazil and that innovation is effective for reducing environmental impact. However, it can also be observed that one of the central issues in this debate is the fact that many organizations still see environmental questions as a source of costs rather than opportunities.

It can be stated that the majority of organizations consider innovation and technology to be indispensable, particularly with relation to environmental issues. Working from the premise that innovation can be usefully analyzed from two different perspectives, specifically, (a) as a driver of economic benefit, and (b) as a source of environmental impact (positive or negative), this study analyzes the environmental impacts of innovation in companies doing business in the chemical industry in the Sinos Valley region, Rio Grande do Sul, Brazil, using qualitative, quantitative, descriptive and exploratory methods, with a view to identify innovation in these firms, the environmental characteristics and the results of this innovation.

\section{Innovation}

Joseph Alois Schumpeter was a pioneer and one of the most important authors of literature on the subject and the person who most emphasized the relevance of innovation to economic development. According to Schumpeter (1982), innovation is the introduction of a new good to the market or a new quality of a good, introduction of a new method of production, opening of a new market, discovery of a new source of raw materials, or implementation of a new organization or method of organization. 
In line with these concepts, Christensen (2002) has stated that innovation can be defined as formulation, combination or synthesis of knowledge to create new products, processes or services. Innovations in processes and services can revolutionize an industry, reducing costs, eliminating the number of production stages, or introducing new types of services.

Schumpeter (1982, p. 48) listed five different types of innovation, as follows,

(1) Introduction of a new good - that is one with which consumers are not yet familiar - or a new quality of a good. (2) Introduction of a new method of production, that is one not yet tested by experience in the branch of manufacture concerned, which need by no means be founded upon a discovery scientifically new, and can also exist in a new way of handling a commodity commercially. (3) Opening of a new market, that is into which the particular branch of manufacture of the country in question has not previously entered, whether or not this market has existed before. (4) Conquest of a new source of supply or raw materials or half-manufactured goods, again irrespective of whether this source already exists or it has first to be created. (5) Carrying out of the new organization of any industry, like the creation of a monopoly position (for example through trustification) discovery or the breaking up of a monopoly position.

As such, innovation is basically the introduction of a new product and/or process, a new market, or use of new materials and/or new market structures.

Kemp, Smith and Becher (2000) consider that the literature on innovation can basically be divided into two different approaches. The first approach analyzes the behavior of innovative individuals, starting from the premise that companies innovate through technological opportunities and that innovations occur where there are opportunities. The second approach considers innovation within a systemic concept of complex interactions between companies and their environments. However, the scope of this paper is limited to identification of innovation as a result rather than as a process. In other words, innovation is seen as a product or process or something new to the firm, rather than the way in which organizations manage the innovation process.

Bessant and Tidd (2009) have identified innovation types, stating that there are different types of novelty, ranging from minor improvements (incremental innovation) to radical changes that truly transform things, in terms of the way they are perceived or utilized. Sometimes these changes are common and simple and are restricted to specific sectors or activities, but in other cases they are so radical and difficult to achieve that they change the basis of society itself (Bessant \& Tidd, 2009).

Incremental innovations occur continuously in all industries, but vary from country to country and sector to sector as a function of the demand for supply, sociocultural factors, opportunities, etc. This class of innovation includes improvements to product design and quality; improvements to processes; new technological and organizational arrangements; and new practices related to supplies and sales. Radical innovation occurs when existing paths are abandoned and a new technological route is inaugurated. In contrast with incremental innovation, radical innovation is not gradual, but sporadic, breaking through the limits of incremental innovation. Radical innovations lead to jumps in productivity and start off new pathways for incremental innovations (Bessant \& Tidd, 2009).

Some authors (Organização para a Cooperação e Desenvolvimento Econômico [OCDE], 2005; Tidd, Bessant, \& Pavitt, 2008) claim that the most important types of innovation are innovations in products and processes. Innovations in products and processes are strictly related to concepts of technological innovation. The Oslo Manual (OCDE, 2005) extends this set with the addition of innovations in marketing and organizational innovations, expanding the range of innovations (OCDE, 2005). For the purposes of measuring types of information, this study therefore adopted the innovation classification recommended by the Oslo Manual (OCDE, 2005), which is oriented along Schumpeterian lines:

Product innovation: Introduction of a product or service whose characteristics or intended uses are new or significantly improved. This includes significant improvements to technical specifications, components and materials, the software implemented, ease of use, or other functional characteristics. 
Process innovation: Introduction of a new or significantly improved method for production or distribution. This includes significant changes to techniques, equipment and/or software. Marketing innovation: Introduction of a new marketing method with significant changes to product concept or packaging, product positioning, product promotion, or product pricing. Organizational innovation: Implementation of a new organizational method in company's business practices, in workplace organization, or in external relations.

In addition to fitting one of the types described above, for an action to be considered an innovation it must involve a certain degree of change or novelty. The degree of novelty can be discussed in terms of an innovation's scope of diffusion, which may be: new for firm, new for market, or new for global market (OCDE, 2005):

New for firm: the minimum requirement for an innovation is that the change introduced must be new to the firm introducing it. A production, process, marketing or organizational method may already have been utilized by other companies, but if it is new for a specific firm, then its introduction constitutes an innovation for that firm. New for market: innovations are defined as new for market when a firm is the first in its market to introduce a change. A market is defined as the firm and its competitors and may refer to a geographic region or a product line. The geographic scope is subject to the firm's own view of its business market and may include regional or international companies. Finally new for global market: a change is considered innovation for global market when a firm is the first to introduce it to any market or industry, whether domestic or international. As such, global market innovation involves a qualitatively higher degree of novelty than an innovation that is only new for market (OCDE, 2005).

It should be noted that for the purposes of assessment of innovative companies, an innovative firm is one that has implemented an innovation during the analysis period (OCDE, 2005). While literature on the subject emphasizes the importance of innovation, it also calls attention to questions related to the difficulties involved in measuring innovation and in establishing its relationship with companies' performance (Tidd et al., 2008).

Customer orientation has an impact on product development. As customers can particularly drive innovation in small and medium-sized enterprises (SMEs), companies work closely with their customers on contractual work, and often have to develop new products to meet customers' requirements. Sometimes new ideas may come from the customers themselves. Their influence is particularly apparent in new product ideas, new product launches, process innovation, cross-functional teamwork, interdepartmental connection, and, to a lesser extent, in business strategy (Laforet, 2009, 2011; Salavou, Baltas, \& Lioukas, 2004).

Besides market environment, business and quality aspects, for SMEs innovation is driven by a desire to be successful and improve working conditions. Positive outcomes of innovation include an enhancement of SMEs' reputation and image, an increase in operational efficiency and cost benefits, resulting in a better business financial performance, recruitment of a more skilled workforce, and greater in-house expertise leading to further innovation (Laforet, 2011, p. 2).

When dealing with the subject of environmental innovation, it is important to start by covering the wider subject of innovation in general, before narrowing the focus to environmental innovation. From the perspective of management and with an eye on the market, Tigre (2006) defines innovation as the process through which inventions are sometimes transformed into economically sustainable products or systems. With regards to the impact of environmental innovation, the intention is also to identify indications that process costs have been cut and/or product value added has been increased and to analyze the impact on environmental issues.

\section{Environmental innovation}

According to Konnola, Carrillo-Hermosilla and Gonzalez (2009), the challenges of global economic competitiveness, social inequalities and the dimension of environmental problems have raised awareness and increased concerns about the need to change and renew the technological status quo and 
current patterns of social behavior. They observed that economic stimuli aimed at lowering environmental impacts can produce innovative solutions, which gradually move society to a more sustainable form of development.

Daroit and Nascimento (2004) approach is entirely linked to the economic focus and innovation is exclusively treated as a way for companies to achieve extra profits, utilizing the competitive advantages generated by production of new products or processes that increase customer value. Notwithstanding, they do point out that organizations need to improve their understanding of the role of innovation in terms of its effects on society and on the environment.

Munoz, Coelho and Steil (2010) analyzed definitions of environmental innovation used in articles describing empirical research and found that the majority of articles did not mention any key concept of innovation focused on reducing environmental impacts. They found definitions for eco-innovation and for environmental, social or sustainable innovation, plus passages relating to environmental technology and ecological innovation. According to these authors, the number of definitions of environmental innovation is greater than the other key concepts of innovation for sustainability.

Porter and Van der Linde (1995) consider that environmental innovation is using the mix of inputs (raw materials, energy and labor) in a more productive manner, thereby compensating for the costs of reducing environmental impacts and resolving the ecology vs. economy dilemma. In addition to the concept of environmental innovation, there are also references to other terms in the literature.

Of particular prominence is the term eco-innovation, which Reid and Miedzinski (2008) state means creation of new products at competitive prices and using processes, systems, services and procedures designed to satisfy people's needs and offer better quality of life for all, while using the minimum natural resources per unit produced and releasing a minimum of toxic substances. Other definitions of eco-innovation consider attributes of new processes, products and methods from a technoecological perspective (Kemp, Smith, \& Becher, 2010). For example, the Measuring Eco-Innovation (MEI) research project defines eco-innovation as the production, assimilation or exploitation of a product, production process, service or management or business method that is novel to the organization and which results, throughout its life cycle, in a reduction of environmental risks, pollution and other negative impacts of resources use (including energy use) compared to relevant alternatives (Cainelli \& Mazzanti, 2013; Kemp \& Pearson, 2007).

As will be observed, the two terms (environmental innovation and eco-innovation) tend to the same direction, so for the purposes of this article the term environmental innovation will be adopted. According to Kemp and Arundel (1998), Rennings (2000), Rennings and Zwick (2002) and Beise and Rennings (2005), environmental innovations consist of new or modified processes, techniques, practices, systems and products for avoiding or reducing environmental damage. Environmental innovations can be developed with or without an explicit objective of reducing environmental damage (Cainelli \& Mazzanti, 2013). They may also be motivated by typical business objectives, such as profitability or product quality maximization. Additionally, many environmental innovations combine environmental benefits for corporations and users (Beise \& Rennings, 2005). Rennings, Ziegler, Ankeleband and Hoffman (2006) point out that environmental product innovations have a positive impact on learning processes in environmental management systems. These learning processes and innovations in environmental processes also have a positive influence on economic performance.

The general definition of an innovation considers three elements: it must be based on knowledge of new technologies, it must have been implemented (i.e. new products must have been launched on the market or new processes must have been introduced by the firm); the innovation may be new for the firm but does not necessarily have to be new for the market; innovations in environmental technologies are innovations in new or modified products and processes designed to avoid or reduce environmental load (Rennings \& Zwick, 2002).

Development of indicators for environmental issues is very important for companies, providing references for measuring the environmental behavior and results of industry. Kemp and Arundel (1998) 
pointed out that the development of indicators of environmental innovation should reflect the fact that all aspects of production can affect the environment: from choice of materials to specification of the production processes characteristics and the products manufactured. Additionally, environmental impacts are not restricted to the production phase, but can occur throughout the entire life cycle of a product.

There are two main forms of classifying environmental innovations. The first is based on the motivations or reasons for the development of these innovations, whereas the second focuses on their objective. Environmental innovations may be specifically developed in order to reduce environmental damage or their environmental benefits may be a side effect of attempting to achieve other objectives. Kemp et al. (2000) provide using flue-stack scrubbers to remove sulfur dioxide as an example of the first type, which it is easy to identify as an environmental innovation. In contrast, the second class comprises innovations that were originally developed for non-environmental objectives, but have had beneficial environmental effects (Kemp \& Arundel, 1998).

Kemp and Arundel (1998) therefore state that the existence of two classes of environmental innovations requires two sets of indicators: one for innovations developed in response to regulations (conformity innovations) and another that could identify environmental components of other types of innovations (Quitzow, Walz, Köhler, \& Rennings, 2014; Rennings \& Smidt, 2010). As such, there are also two major categories of objectives or applications of environmental innovations. The first includes end-of-pipe solutions in which a technology is applied to a preexisting production system. The second consists of clean technologies that reduce the production of pollutants or energy and materials inputs. These two large categories can be further subdivided into six types of environmental innovation (Arundel \& Kemp, 2009; Kemp \& Arundel, 1998):

1. Pollution control: technologies to prevent direct release of substances harmful to the environment into the air, surface water or soil.

2. Waste management: handling, treatment and elimination of waste, both on-site by the producer of the waste and when conducted off-site by waste management companies.

3. Clean technology: process-integrated changes in production technology that reduce the quantities of pollutants and waste generated during production.

4. Recycling: reducing waste by reutilization of materials recovered by managing waste streams.

5. Clean products: products that cause low environmental impact throughout the entire life cycle of design, production, use and disposal. Examples of this type of technology include low-solvent paints and bicycles.

6. Clean-up technology: remediation technologies, such as air and soil cleaning and the use of bioremediation agriculture, which employs specific plant species to remove toxic materials from contaminated soils.

Additionally, the same forces have identified three categories of environmental innovation: clean technology products, recycling and cleaning, which could be developed in response to regulations or for other reasons. Similarly, recycling technologies can be applied in the contexts of both remediation and clean technologies (Kemp \& Arundel, 1998).

In adherence to our research objectives, our specific intention here is to measure environmental innovation in the chemical industry with three foci. These elements are drawn from the study by Arundel and Kemp (2009), in which they present three aspects that should be measured on a macro level, specifically, the nature of environmental innovation and its scope of application; the conductors of and barriers to environmental innovation; and the effects of environmental innovation, as follows:

1. The nature of environmental innovation and its scope of application: it is necessary to understand the nature of environmental innovation to effectively measure it. Each environmental innovation is 
unique from a given perspective and according to the many different attempts to create a system for their classification. It has proven difficult to reach a widespread and international agreement on what constitutes environmental innovations, primarily because many innovations have a range of applications, in addition to environmental protection, making development of indicators difficult.

2. Conductors of and barriers to environmental innovation: conductors of environmental innovation are regulations, demand from users, exploitation of new markets, cost reductions and institutional reputation. This study does not attempt to go further and will not measure barriers to innovation, only considering the resulting innovations and the motives driving their development.

3. Effects of environmental innovation: environmental innovation helps to achieve a balance between economic growth and environmental protection. The consequences of economic growth and increasing employment are not simple and can vary depending on the type of environmental innovation and the context in which it is used.

Rennings and Zwick (2002) interviewed 1,594 companies in their IMPRESS survey and analysis of the results showed that $34.4 \%$ of these firms developed environmentally beneficial innovations that were not introduced to meet environmental legislation or regulations. Additionally, they reported that the three most common reasons given for the introduction of environmental technology were improving the firm's image, compliance with environmental regulation, and costs reduction.

They also emphasized the finding that a firm does not decide to change its products, its processes, its routines and its way of organizing work in response to its share of social responsibility for improving the environment. What determines the adoption of an innovative strategy is the pressure coming from the supply side, i.e. technology push; demand-side pressures, i.e., demand push, which focus on the business environment and highlight regulatory requirements; the possibility of cutting costs or increasing profits; public pressure to reduce industrial pollution and increase safety; and also pressure from workers (Ashford, 2000; Ferreira \& Kiperstok, 2007). The implementation of innovative technologies may be also motivated by the company's desire to gain market advantages, such as regulatory advantage. In this regard, it is worth noting the role of, environmental regulations, which tackle environmental challenges of increasing global relevance and may induce the development and international diffusion of corresponding environmental innovations via the mechanisms outlined above (Quitzow et al., 2014). In addition, the role of regulatory sector factors confirms the induced innovation hypothesis (Cainelli, Mazzanti, \& Montresor, 2012).

Along the same lines, Kemp and Arundel (1998) proposed a structure for identification of the motives and drivers leading companies to develop environmental innovations, consisting of the following: customer or consumer demands; demands from investors or shareholders; compliance with environmental standards; environmental regulations; cutting production costs; employee safety; and demands from environmentalist and citizens' groups and movements.

According to Andersen (2006), the field of environmental innovation is still poorly supplied with statistics and indicators and the challenge lies in attempting to combine two important pictures of development of environmental innovation: the innovation system or chain and environmental technology seen from a wider perspective.

Authors like Rennings et al. (2006), Quitzow, Walz, Köhler and Rennings (2014), Cainelli and Mazzanti (2013) state that innovation indicators are intended to measure the innovation capacity of agents, which could be a country, a region, a business sector or a firm. Additionally, metrics may refer to innovation outputs (numbers of new products launched to market, product knowledge intensity, numbers of patents, market share, etc.) or to innovation inputs that provide the basis for innovation (investments in research and education, numbers of bibliographic citations, knowledge flows, etc.). It is important to state that the intention of this study is to measure innovation outputs, identifying what has been developed and the results.

Finally, working with the concepts of environmental innovation, the structure employed to analyze innovation and its environmental characteristics in this study will be guided by identification of 
the following items: types of innovations, environmental benefits of innovations, environmental characteristics (technology and focus of application), and the motivations driving these innovations and their impacts within the organizations implementing them.

\section{Characteristics of the chemical industry}

The chemical industry is not only considered strategic because of its capacity to provide wellpaid work for qualified workers, but also because of its contributions to other economic activities and to consumption. For example, products from the chemical industry can be found in agriculture, mining, in the petroleum industry, in manufacturing, in the transport industry, in services sectors (including healthcare), and in a large proportion of packaging. This also explains why the industry exhibits expansion rates that are higher than the mean growth in gross domestic product (GDP) (Associação Brasileira da Indústria Química [Abiquim], 2010).

The Brazilian chemical industry ranks ninth in the world and accounts for 3.5\% of GDP and for around $12 \%$ of the product of the manufacturing industries, making it the second largest industrial sector in Brazil.

This description of the characteristics about the object of study shows that the chemical industry owes its importance to the fact that it is both local and present in practically all other economic activities because of its considerable contribution to the economy of Rio Grande do Sul state. This sector of Brazilian industry has exhibited growth in development of new products and processes and has a great potential for causing environmental impacts, being often the target of regulatory initiatives focused on environmental issues.

\section{Research Methods}

In terms of its objectives, this study can be described as descriptive, recording and describing the facts observed without interfering with them and describing the characteristics of a specific population or phenomenon, in addition to establishing relationships between variables. The authors chose a quantitative approach, which, from a procedural point of view, signifies that the following stages were conducted: a bibliographic review, a documentary study, and, finally, an analysis of data collected by survey.

A questionnaire ${ }^{(1)}$ was constructed to conduct a survey of companies in the chemical industry located in the Sinos Valley area. The questions were constructed with reference to the literature analyzing the results of innovation, type and degree of innovation, motivations of innovation, and environmental technologies, of which the most important contributions came from the following sources: the Oslo Manual, Schumpeter and the Bogotá Manual, and also Rennings (2000), Kemp and Arundel (1998) and Beise and Rennings (2005), for questions related to environmental innovation.

A 5-point Likert scale was used, where one (1) is considered as incremental or irrelevant innovation and five (5) as radical or extremely important innovation. The questionnaire was prepared from the theoretical review, underwent a validation process involving review by four specialist experts, and was pre-tested in a pilot study. The instrument was further validated using scored reviewing by judges, followed by calculation of a Coefficient of Content Validity (CCV), as described by HernándezNieto (2002) and consisting of the ratio between mean score for each item and the maximum possible item score, with items considered adequate if they have coefficients greater than or equal to 0.8 . The coefficient is calculated as follows: $\mathrm{CCV}=(\mathrm{MPS} / \mathrm{MS})$, where: MPS $=$ Mean Points Scored (total score/number of judges); and MS = Maximum Score possible, per judge.

The advantage of this technique lies in the peer review element, since it is an independent expert assessment in the form of value judgments on the aspects Clarity of Language, Practical Relevance and 
Theoretical Dimension, awarding a score for each of the first two along a scale and identifying the third from groups of possible variables. The number of judges recommended is from 3 to 5 (Fenker \& Diehl, 2009; Hernández-Nieto, 2002).

After analysis of the judges' assessments (Table 1), some items were not considered adequate (because they scored below 0.8) and were maintained but corrected with reference to the judges' observations.

Table 1

CCV - Coefficient of Content Validity

\begin{tabular}{ccccccccc}
\hline \multicolumn{8}{c}{ CCV - Coefficient of Content Validity } \\
\hline \multicolumn{7}{c}{ Clarity of Language } \\
\hline Profile & 1 & 2 & 3 & 4 & 5 & 6 & 7 & 8 \\
0.96 & 0.92 & 0.72 & 0.84 & 0.76 & 0.84 & 0.84 & 0.88 & 0.84 \\
\hline & & \multicolumn{8}{c}{ Practical Relevance } & & & \\
Profile & 1 & 2 & 3 & 4 & 5 & 6 & 7 & 8 \\
1 & 1 & 0.96 & 0.96 & 1 & 1 & 1 & 0.96 & 0.72 \\
\hline & 1 & 2 & 3 & 4 & 5 & 6 & 7 & 8 \\
\hline Profile & 1 & 0.88 & 0.84 & 0.84 & 1 & 1 & 1 & 0.84 \\
\hline
\end{tabular}

Note. Source: The authors.

After the analysis by judges, a pre-test was conducted with 15 companies chosen at random. The questionnaire was conducted by telephone calls and all aspects were analyzed, including item content, text, sequence, format and layout, item difficulty and instructions. When the pretest was complete, it was concluded that it was not necessary to make further changes to the questionnaire and the same questionnaire was used for data collection with all of the other companies.

The study population was defined as all chemical companies located in the Sinos Valley area listed in the database of the FIERGS industrial association (Federação das Indústrias do Estado do Rio Grande do Sul [FIERGS], 2013), totaling 108 companies. However, after contacting the companies and reviewing the database, the number was reduced to 85 companies, 50 of which answered the questionnaire, equating to $58.8 \%$ of the total number of companies. The sample method was therefore by convenience and the questionnaire was only administered to companies who had someone available during the data collection period, which ran from $1^{\text {st }}$ November to $31^{\text {st }}$ December of 2013. Considering sample characteristics and the small amount of observations available, a more sophisticated statistical analysis segregating data into size and operating time categories or industry segment was not able to be performed. Therefore, analysis considered the sample as a single set of data (Malhotra, 2001).

Descriptive statistics were first calculated for the data from the quantitative study, in the form of frequencies, and then, in possession of the factors, an analysis was conducted to attempt to identify possible relationships or similarities between constructs. 


\section{Analysis and Discussion of Results}

This section of the paper presents a description of the characteristics of the chemical industry and the profile of the companies surveyed, including size in terms of number of employees and total earnings. This description is part of the justification for this study, delineating the context of the chemical industry, in order to identify where its innovations emerge.

The section is subdivided into the following topics: innovation, which is intended to identify types and degrees of novelty from innovations; and environmental innovation, which is intended to identify the environmental characteristics of innovations, such as type of technologies used and the motivations for development of these technologies.

As mentioned with relation to study methodology, a total of 85 chemical companies from the Sinos Valley region in the Brazilian state of Rio Grande do Sul were approached. Of these, 50 organizations answered the questionnaire and they comprise the convenience sample employed for this study. In terms of number of employees, the companies surveyed breakdown as follows: 26 companies had 19 employees or fewer, 11 companies had from 20 to 99 employees, 11 companies had from 100 to 499 employees, and 2 companies had more than 499 employees. This allowed firm size to be analyzed using a classification recommended by the small business support service, Serviço Brasileiro de Apoio às Micro e Pequenas Empresas (SEBRAE, 2009), showing that the sample contains a concentration of micro and small enterprises, with $74 \%$ of firms surveyed falling into one of these two categories.

With regard to the location of the participating companies, firms were mostly located in the cities of Canoas (10), Novo Hamburgo (10), Portão (6), São Leopoldo (5), and Estância Velha (5). Furthermore, three answers were classified into the item others, including three cities which are not located in the Sinos Valley region due to the fact that, even though the company's headquarters are located in the region, the person in charge of answering the survey was working at a different branch of the company, outside the Sinos Valley region. Concerning operating time, most companies participating in the research hold more than 15 years of operation or 16 to 30 years; if both ranges are comprised, they account for $76 \%$ of the sample.

\section{Innovation}

The conceptual model that guides this analysis considers innovation to be the introduction of a new good to the market or a new quality of a good, development of a new method of production, opening of a new market, discovery of new raw materials or establishment of new organizations or methods of organization (Schumpeter, 1982).

Initially, new products and/or processes (production, marketing or organizational) developed by the companies over the previous 3 years were identified and these innovations were classified as new or as improvements, considering whether their degree of novelty was at the level of the firm, the domestic market or the international market, and identifying them as radical or incremental in nature. As such, according to the companies surveyed, innovation was characterized as new products, new processes and use of new components or new raw materials. It was clear that these new products or processes did not need to be new to the market, it was sufficient that they were new to the firm that implemented/developed the innovation (OCDE, 2005).

The companies surveyed were requested to rate the characteristics of innovations and their degree of novelty on a scale from 1 to 5 , along which 1 represents incremental innovation and 5 completely radical innovation. The results showed that the types of innovation that had the highest mean scores (i.e. were given a higher innovation index, closer to the completely radical end of the scale) were product innovation for the domestic market (3.08), new for firm marketing innovation (3.07), and new for firm and new for domestic market process innovation (3.06). 
These findings show that the priority is product innovation: introduction of a product or service whose characteristics or intended uses are new or significantly improved. It can also be observed that on the domestic market level, the principal types of innovation are in products and processes, which are closely related to the concepts of technological innovation (OCDE, 2005; Tidd et al., 2008).

As was reported by the 2008 PINTEC survey (IBGE, 2010), the greatest intensity is observed in product innovation for the domestic market, with $72.5 \%$ of companies innovating in products at this level, compared with a total percentage of companies innovating in products of $85 \%$. The picture is similar for process innovations in the domestic market, with $60.0 \%$ of the companies innovating, while the total percentage of companies innovating in processes at any level was $82.5 \%$. A certain difficulty is perceived with relation to measurement of process innovations and in the majority of cases these innovations are considered to be only novelties for the firm in question, in addition to the fact that these innovations can be developed in a varying and ad hoc manner, which further increases problems of measurement.

As described in the Oslo Manual (OCDE, 2005), one of the results of innovation, and especially of process innovation, tends to be a change in production functions, i.e., a change in the use of the factors of production, which contributed to the analysis. As a result, it was observed that companies find it hard to measure process innovations, because they affect day-to-day processes involving on-the-spot issues, and this is particularly true of micro and small enterprises. It has been emphasized that one of the main reasons for the low level of innovation in Brazilian industry is the low volume of resources dedicated to innovation activities, particularly internal and external research and development activities (IBGE, 2010).

Analysis of data by firm size, using cluster analysis, did not reveal any similarities between the companies. According to Zucatto, Silva and Pedrozo (2011), these innovations have a certain technological leveling effect on companies. If on one hand it is considered that innovations offer firms greater competitiveness, this is true of large size companies that they can develop new technologies by themselves; however, on the other hand, in the case of small and medium size companies, innovation takes place almost concomitantly, which generally lifts companies that adopt these technologies to new levels of competitiveness, but without significant differences between them or between companies of the same size.

To a certain extent, it can be observed that there was a greater tendency to implement innovations of an incremental type, which is the more elementary and gradual level of change, and which happens continuously in any type of industry. According to the Oslo Manual (OCDE, 2005) and to Tidd, Bessant and Pavitt (2008), radical innovations occur when existing paths are abandoned and new technological routes are founded. In contrast with incremental innovation, radical innovation is not gradual, but sporadic, breaking through the limits of incremental innovation. As such, it can be observed that the results of this study are aligned with authors who claim that incremental innovation takes place in a continuous manner in any type of industry and does not cause such intense ruptures as radical innovation.

Also of note in the results is the finding that innovations were predominantly novelties for the firms and/or their domestic markets, which in turn may explain the low mean scores for global market innovations, since these companies seek out technologies that already exist on the international market and adapt them to their own organizations and to the domestic market. As such, these results reflect a characteristic of Brazilian industry that has been identified by the PINTEC survey (IBGE, 2010), with respect to both product and process innovations, since the great majority were firm innovations, with a small number of domestic market innovations and an even smaller number of global market innovations. It was also observed that the majority of innovations are improvements to already-existing products or processes.

With regard to this, it is of note that one of the main reasons for the low level of innovation by Brazilian industry is the low volumes of resources dedicated to innovation activities, especially to internal and external research and development (IBGE, 2010). Having analyzed innovation in the 
chemical industry, the next section presents an analysis of innovations that contribute to minimizing environmental impact, identifying the motivations that drive companies to develop innovations with reduced environmental impacts, their principal characteristics and their technological focus.

\section{Environmental innovation}

This section covers analysis of environmental impact, which is the focus of the present study, following proposals made by Arundel and Kemp (2009). The analysis is divided into three parts, starting with observation of the conductors and/or motivations for development of the technology; followed by examination of the innovations' nature, i.e. the technology developed; and ending with the types of innovation (process and/or product) and their environmental contributions and effects.

The reasons or motivations for companies to develop technologies with lower environmental impacts are analyzed in line with Kemp and Arundel (1998), who identified the following elements: customer or consumer demands; demands from investors or shareholders; compliance with environmental standards; environmental regulations; production costs reduction; employee safety; and demands from environmental or citizens groups and movements.

All of these options were given mean scores considered significant, indicating that the whole set of elements listed by Kemp and Arundel (1998) is important and that all elements contribute to driving companies to develop technologies with reduced environmental impacts. Notwithstanding, the reasons that scored highest were: employee safety (4.64 points), compliance with environmental standards and production costs reduction (4.56 points), and environmental regulations (4.46 points).

As such, it can be observed that this study bears a similarity to the study conducted by Kemp and Arundel (1998), in which they detected the existence of two classes of environmental innovations, requiring two sets of indicators: one for innovations developed in response to regulations (conformity innovations) and another that can identify the environmental components of other types of innovations.

Additionally, it was observed that there were several innovations that had elements related to environmental questions and that these were almost exclusively the result of compliance with environmental legislation, requirements and demands from customers to meet standards, primarily in the case of export products. This bears out Zucatto et al. (2011), who reported that innovations occur in order to comply with legislation, because of customer requirements, obligations or because they are needed to become eligible for public tenders.

It can be considered that what determines adoption of an innovative strategy are the pressures of supply, since it is demand-side pressures that are brought to bear on the business market. Also identified are regulatory requirements, the possibility of cutting costs and/or increasing profits, public pressure to reduce industrial pollution and increase safety, in addition to pressure from workers (Ashford, 2000; Ferreira \& Kiperstok, 2007).

Having analyzed the motivations for development of innovations, the environmental technologies developed by these companies will be discussed. The principal results are as follows: systems for disposal and reduction of waste (4.16 points), clean products that cause reduced environmental impact (4.13 points) and clean technologies or integrated production process technology (4.02 points). It was found that, in common with other studies, these companies continue to focus on reduction of consumption and of waste, on processes and on concerns with reuse of certain waste products, rather than with development and utilization of new technologies. Therefore, as Rennings and Zwick (2002) pointed out, the principal concern of these companies is with end-of-pipe technologies or remediation methods, which act by controlling pollution after the emissions have been generated and environmental problems created.

In order to ground the results of this study, we present results reported by Malamam (1996 as cited in Kemp \& Arundel, 1998), who classified innovations into seven categories: cleaner products $(28.6 \%)$, energy-saving technologies $(8.3 \%)$, cleaner production processes $(25.5 \%)$, recovery and 
recycling technologies (23.4\%), end-of-pipe technologies (3.6\%), products which modify production processes $(8.3 \%)$, and environmental diagnostic and monitoring (1.0\%). As mentioned, these results bear a similarity to the case studied here, with the single exception of development of clean technologies, which was considered one of the most important results in Malamam's study.

As mentioned above, in the present study, the issues identified as the most important were technologies for remediation or prevention of environmental damage. However, Malamam's study (1996 as cited in Kemp \& Arundel, 1998) reported contrasting results for clean technologies, which leads to reflections on the need for these innovations in the companies surveyed here, since these technologies require greater resource investment, but also provide better economic results.

Still with relation to Barbieri's theory (2006), the companies surveyed develop technologies of a corrective nature, and their environmental management is at the initial phase, at which the demands of environmental legislation are seen as problems to be solved by the firm's technical and operational organs, without decision-making autonomy, and as an additional internal cost. From the environmental point of view, pollution control practices are poorer solutions because they focus on the effects and not on the causes of pollution and because they offer little return on the volume of resources that firms invest.

Additionally, there was also the development of cleaner production technologies, which have a direct impact in reduction of environmentally harmful impacts during the production process. Recycling of materials, utilization of ecological materials (for example, substituting organic solvents with water) and refitting processes with integrated systems are examples of cleaner production technologies (Rennings, 2000). It was possible to discern that the primary benefits of these innovations are cost savings, whether through reducing energy and water consumption or waste generation, in addition to offering increased customer acceptance of the resulting products, which is one of the elements covered in the analysis of the focus of environmental technologies that follows.

With the objective of refining the analysis of development of technologies, the foci of the technologies developed were analyzed, identifying their principal characteristics, such as: reduction of intensity of materials consumption; reduction of energy intensity; reduction of release of toxic substances; increasing recyclability; optimization of utilization of renewable materials; extension of product lifecycles; increasing the intensity of service added. These items are primarily based on the results of the interviews conducted and also on the concept of eco-efficiency developed by the World Business Council for Sustainable Development (WBCSD, 2000) and they are management indicators for guidance and assessment of companies developing and concerned about environmental performance.

As such, all of these items are considered important. However, some of these items were identified as the most important for the product innovations developed, as follows: materials consumption intensity reduction (4.20 points); renewable materials utilization optimization (4.15 points); and increasing the intensity of service added (4.15 points). For process innovation, the items of greatest note were: increasing recyclability (4.24 points); toxic substances release reduction (4.20 points); and increasing the intensity of service added (4.20 points).

A general overview of the environmental technologies in the waste production chain shows that there are different paths for reducing resource utilization, generating less waste, and reducing pollutant emissions. These different options can be arranged into a hierarchy, running from the best to the least efficient, as follows: elimination of waste, reduction at source, recycling (internal \& external), treatment and disposal (Kemp \& Arundel, 1998). As such, objectives focused on reduction of waste and on creating synergies with by-products can lead to more efficient use of resources within a process and create an additional financial benefit. In short, companies become eco-efficient because to do so allows them to create more value with fewer resources.

Additionally, it can be observed that one of the principal results of product and process innovations is the increase in intensity of service added, since selling a service rather than the product itself makes it more likely that the client can have the same functional need met using fewer materials 
and resources. It also makes it more likely that the materials cycle can be closed, since responsibility, ownership and, as a consequence, concern for efficient use remains on the service-provider side.

Among the many questions analyzed and related to theory, it was observed that companies attempt to re-engineer and adapt their processes to reduce consumption of resources, to reduce pollution and to avert risks, at the same time that they make cost savings. Additionally, process changes may also be related to the suppliers' activity, to distribution, to the use customers have for them, or to disposal (WBCSD, 2000).

It was also found that these issues are more visible and are requirements of the companies. This supports a hypothesis proposed by Porter and Van der Linde (1995), who pointed out to the existence of synergies between competitiveness and environmental preservation, consisting of imposition of adequate environmental norms and standards that will be capable of driving companies to adopt innovations to reduce their costs or to add value to their products and processes.

As such, the results of this study are similar to those reported by Silva and Sicsu (2003), who identified a number of positive results that can be achieved with environmental technologies, such as: cost reductions, originating in lower consumption of natural resources and less generation of waste; the possibility of selling to international markets having met trading standards; compliance with relevant environmental legislation; improved corporate image because of implementation of a responsible management model.

Table 2

\section{Synthetic Summary of Study Results}

\begin{tabular}{|c|c|c|}
\hline \multicolumn{3}{|c|}{ Table of synthetic results } \\
\hline \multirow{3}{*}{$\begin{array}{l}\text { Type and } \\
\text { degree of } \\
\text { innovation }\end{array}$} & & nnovation in product (3.01 points) \\
\hline & Prod & ovation for the domestic market (3.08 points) \\
\hline & New for firm a & $\mathrm{v}$ for domestic market process innovation (3.06 points) \\
\hline \multirow{3}{*}{$\begin{array}{l}\text { Motivations for } \\
\text { innovation }\end{array}$} & & Employee safety (4.64 points) \\
\hline & Compliance with en & ental standards and production costs reduction ( 4.56 points) \\
\hline & & vironmental regulations ( 4.46 points) \\
\hline \multirow{7}{*}{$\begin{array}{l}\text { Environmental } \\
\text { technologies }\end{array}$} & Syste & disposal and reduction of waste ( 4.16 points) \\
\hline & Clean produ & it cause reduced environmental impact ( 4.13 points) \\
\hline & Clean technolo & integrated production process technology (4.02 points) \\
\hline & Results of product & Materials consumption intensity reduction (4.20 points) \\
\hline & innovations developed & Renewable materials utilization optimization ( 4.15 points) \\
\hline & Results of process & Increasing recyclability (4.24 points) \\
\hline & innovation & Reduction of release of toxic substances ( 4.20 points) \\
\hline
\end{tabular}

Note. Source: The authors.

Additionally, with regard to environmental issues (Table 2), the innovations in products or processes observed in the companies surveyed were not spontaneous or motivated by customers' wishes, but were the result of legislation, of compliance with standards, and of customer requirements. As such, the pressures are in line with the prevention logic, leading firms to achieve competitive advantages by reduction or elimination of their environmental liabilities. This indicates that environmental regulation 
is acting in the correct manner, as a demand-side pressure, contributing to reducing production costs and to improving the environment and the organizations themselves.

In general, the results of this study exhibit a relationship with Arundel and Kemp's study (2009), in which the conductors of environmental innovation were found to be regulations, demand from users, expansion into new markets, cost reduction, and corporate image building, in addition to comply with legislation, which can stimulate environmental technologies. In the present study, this is aligned with the results of regulations, environmental impact and productivity, as mentioned earlier. This demonstrates the importance of standards and legislation which contribute to the development of new environmental technologies, driving companies to adopt innovations that reduce costs and/or add value to their products and/or services.

Finally, the issues covered in this section reinforce the environmental innovation theory (Arundel \& Kemp, 2009; Barbieri, 2006; Rennings, 2000) that states companies currently work to meet standards and reduce cost, which is a process that is already proving significantly beneficial to these organizations. Notwithstanding, there are also great opportunities for these companies to develop technologies with higher added value, which could make even greater contributions to economic growth and to reducing environmental impacts.

Finally, it is important to emphasize that the study analyzed the relevance of the subject in a region that is highly dependent on the sector in question, which has a great environmental impact. Therefore, it was observed that participating companies were more concerned about meeting regulatory and clients' requirements rather than developing technologies to reduce environmental impacts that can contribute even more with economic growth and environmental impact reduction.

\section{Final Comments}

This study investigated innovation at the level of organizations, identifying the environmental characteristics and impacts of innovations developed by chemical companies in the Sinos Valley region, Brazil. The first stage of the research was of an explanatory nature. This phase provided highly relevant data and information on the chemical industry in Brazil, in Rio Grande do Sul and in the Sinos Valley. Of particular note among the results is a description of the principal characteristics of the chemical industry, including its segments and structural profile of the market, establishing a relationship with the results of the PINTEC survey (IBGE, 2010), which showed that the proportion of companies that had developed product and process innovations had grown, in comparison to the results of surveys conducted in 2003 and 2005.

With regard to introduction of innovations, and innovation pattern was identified with predominantly incremental characteristics, both in terms of process and product innovations. On a more specific level, the analysis also revealed a predominance of product innovations, reflecting a convergence with the PINTEC analysis (IBGE, 2010) and agreeing with Tidd et al. (2008). It was also noted that the principal types of innovation at the level of the domestic market were innovations in products and processes, which, according to the literature discussing this subject (OCDE, 2005; Tidd $e t$ $a l ., 2008)$, bears out the concepts of technological innovation.

With regard to the benefits of these innovations, it was found that the principal advantages are related to the market (expansion and preservation of markets), to product quality (quality improvement or extension of product range) and to processes (cost reductions and increases in production capacity). Additionally, another positive result was the introduction of environmentally correct products by the organizations surveyed.

Identification of environmental technologies developed by these companies, in addition to their characteristics and the motivations leading them to conduct these innovations, clearly revealed that these companies focus on reducing waste and consumption, on processes and on reutilization of certain waste 
products. It can therefore be considered that the main concern of these companies is with end-of-tube and remediation technologies which act to control pollution after emissions have been generated and environmental problems created, as described by Barbieri (2006).

With regard to the impact of innovation, the results showed that these companies were sensitive to the impacts on several different dimensions of their businesses, both in terms of production processes and in terms of products. This is because, according to the Oslo Manual (OCDE, 2005), the impacts that innovations have on firm performance vary according to their effects on sales and on the market share held, leading to changes to productivity and efficiency of products.

Additionally, it was also observed that one of the main results of product and process innovations is to increase the intensity of service added, which means that a service rather than a product is sold, making it possible for a customer to have the same need met using fewer materials and resources. As such, reduction of waste and identification of synergies with byproducts lead to more efficient resource utilization, enabling increased value creation.

One limitation of this study must be mentioned, in the form of a suggestion for future studies, which is to identify the impacts of innovation, since, according to Horbach, Rammer and Rennings (2011), it is possible to identify whether the technologies implemented reduce energy use, CO2 emissions and water pollution and increase recycling of water and other materials. For example, it would be interesting to analyze differences in technologies and the resulting impacts between companies doing business in Europe and companies in Brazil, identifying their characteristics and proposing improvements in operations, while raising awareness about development of new technologies and concerns about the environment in the country.

\section{Note}

${ }^{1}$ The gathering data tool used during the study can be found by contacting the authors of the article via the following e-mail addresses: dusan@feevale.br or uelinton@feevale.br.

\section{References}

Andersen, M. M. (2006). Eco-innovation indicators. European Environment Agency, Copenhagen, Denmark.

Retrieved

from http://orbit.dtu.dk/fedora/objects/orbit:79881/datastreams/file_115329898/content

Andrade, T. (2004). Inovação tecnológica e meio ambiente: a construção de novos enfoques. Ambiente \& Sociedade, 7(1), 89-105. doi: 10.1590/S1414-753X2004000100006

Arundel, A., \& Kemp, R. (2009). Measuring eco-innovation [UNU-MERIT Working Paper Series \#2009-017]. United Nations University - Maastricht Economic and Social Research and Training Centre on Innovation and Technology, Maastricht, The Netherlands. Retrieved from http://www.merit.unu.edu/publications/wppdf/2009/wp2009-017.pdf

Ashford, N. A. (2000). An innovation-based strategy for a sustainable environment. In J. Hemmelskamp, K. Rennings, \& F. Leone (Eds.), Innovation-oriented environmental regulation (Vol. 1, pp. 67-107). Heidelberg: Physica-Verlag. doi: 10.1007/978-3-662-12069-9_5

Associação Brasileira da Indústria Química. (2010). Pacto nacional da indústria química. São Paulo, SP, Brasil. Retrieved from http://canais.abiquim.org.br/pacto/Pacto_Nacional_Abiquim.pdf 
Barbieri, J. C. (2006). Gestão ambiental empresarial: conceitos, modelos e instrumentos. São Paulo, SP: Saraiva.

Beise, M., \& Rennings, K. (2005). Lead markets and regulation: a framework for analyzing the international diffusion of environmental. Ecological Economics, 52(1), 5-17. doi: 10.1016/j.ecolecon.2004.06.007

Bessant, J., \& Tidd, J. (2009). Inovação e empreendedorismo. Porto Alegre: Bookman.

Cainelli, G., \& Mazzanti, M. (2013). Environmental innovations in services: manufacturing-services integration and policy transmissions. Research Policy, 42(9), 1595-1604. doi: 10.1016/j.respol.2013.05.010

Cainelli, G., Mazzanti, M., \& Montresor, S. (2012). Environmental innovations, local networks and internationalization. Industry and Innovation, 19(8), 697-734. doi: $10.1080 / 13662716.2012 .739782$

Christensen, J. F. (2002). Corporate strategy and the management of innovation and technology. Industrial and Corporate Change, 11(2), 263-288. doi: 10.1093/icc/11.2.263

Daroit, D., \& Nascimento, L. F. (2004, setembro). Dimensões da inovação sob o paradigma do desenvolvimento sustentável. Anais do Encontro Nacional da Associação Nacional de PósGraduação e Pesquisa em Administração, Curitiba, PR, Brasil, 28.

Federação das Indústrias do Estado do Rio Grande do Sul. (2013). Cadastro industrial do Rio Grande do Sul [CD-ROM]. Porto Alegre: Unidade de Estudos Técnicos, Sistema FIERGS.

Fenker, E. A., \& Diehl, C. A. (2009, setembro). Risco e gestão de custos ambientais: avaliação e validação de instrumento de pesquisa. Anais do Encontro Nacional da Associação Nacional de Pós-Graduação e Pesquisa em Administração, São Paulo, SP, Brasil, 33.

Ferreira, M. V. G. de Q., \& Kiperstok, A. (2007). Aplicação de um modelo de processo de inovação ambiental em uma empresa química fina. Revista de Gestão Social e Ambiental, 1(2), 93-110. doi: $10.5773 /$ rgsa.v1i2.25

Hernández-Nieto, R. A. (2002). Contributions to statistical: analysis. Mérida, Venezuela: Universidad de Los Andes.

Horbach, J., Rammer, C., \& Rennings, K. (2011). Determinants of eco-innovations by type of environmental impact - the role of regulatory push-pull, technology push and market pull. Ecological Economics, 78, 112-122. doi: 10.1016/j.ecolecon.2012.04.005

Instituto Brasileiro de Geografia e Estatística. (2010). Pintec - Pesquisa de Inovação Tecnológica 2008. Retrieved http://www.pintec.ibge.gov.br/downloads/PUBLICACAO/Publicacao\%20PINTEC\%202008.pdf

Jaffe, A. B., Newell, R. G., \& Stavins, R. N. (2004). A tale of two market failures: technology and environmental policy. Ecological Economics, 54(1/2), 164-174. doi: 10.1016/j.ecolecon.2004.12.027

Kemp, R., \& Arundel, A. (1998). Survey indicators for environmental innovation [Idea Paper Series]. IDEA Project, Oslo, Norway. Retrieved from http://brage.bibsys.no/xmlui/bitstream/handle/11250/226478/Idea8.pdf?sequence=1

Kemp, R., \& Pearson, P. (2007). Final report of the MEI project measuring eco innovation [Project $\mathrm{N}^{\circ}$ 044513]. UM-MERIT, Maastricht, Netherlands. Retrieved from http://www.oecd.org/env/consumption-innovation/43960830.pdf 
Kemp, R., Smith, K., \& Becher, G. (2000). How should we study the relationship between regulation and innovation? In J. Hemmelskamp, K. Rennings, \& F. Leone (Eds.), Innovation-oriented environmental regulation: theoretical approaches and empirical analysis (pp. 43-66). Heidelberg-New York: Phisica Verlag. doi: 10.1007/978-3-662-12069-9_4

Konnola, T., Carrilo-Hermosilla, J., \& González, P. del R. (2009). Eco-innovation: when sustainability and competitiveness shake hands. Journal of Environmental Assessment Policy and Management, 15(1), 1380001. doi: 10.1142/S146433321380001X

Laforet, S. (2009). Effects of size, market and strategic orientation on innovation. European Journal of Marketing, 43(1/2), 188-212. doi: 10.1108/03090560910923292

Laforet, S. (2011). A framework of organisational innovation and outcomes in SMEs. International Journal of Entrepreneurial Behavior \& Research, 17(4), 380-408. doi: $10.1108 / 13552551111139638$

Malhotra, N. K. (2001). Pesquisa de marketing - uma orientação aplicada. Porto Alegre: Editora Bookman.

Munoz, D. L. C., Coelho, C. C. S. R., \& Steil, A. V. (2010). Inovação para sustentabilidade nas organizações: uma revisão sistemática das abordagens de inovação sustentável, eco-inovação, inovação ambiental e inovação social. Anais do Encontro Internacional sobre Gestão Empresarial e Meio Ambiente, São Paulo, SP, Brasil, 12.

Organização para a Cooperação e Desenvolvimento Econômico. (2005). Manual de Oslo: diretrizes para coleta e interpretação de dados sobre a inovação (3a ed.). Rio de Janeiro: FINEP.

Porter, M., \& Van Der Linde, C. (1995). Toward a new conception of the environment-competitiveness relationship. Journal of Economic Perspective, 9(4), 97-118. doi: 10.1257/jep.9.4.97

Quitzow, R., Walz, R., Köhler, J., \& Rennings, K. (2014). The concept of "lead market" revisited: contribution to environmental innovation theory. Environmental Innovation and Societal Transitions, 10, 4-19. doi: 10.1016/j.eist.2013.11.002

Reid, A., \& Miedzinski, M. (2008). Eco-innovation - final report for sectoral innovation watch. Technopolis Group, Brussels, Belgium. Retrieved from http://www.technopolisgroup.com/resources/downloads/661_report_final.pdf

Rennings, K. (2000). Redefining innovation-eco-innovation research and the contribution from ecological economics. Ecological Economics, 32(2), 319-332. doi: 10.1016/S09218009(99)00112-3

Rennings, K., \& Smidt, W. (2010). A lead market approach towards the emergence and diffusion of coalfired power plant technology [Discussion Paper No. 08-058]. ZEW - Centre for European Economic Research, Mannheim, Germany. doi: 10.2139/ssrn.1261853

Rennings, K., Ziegler, A., Ankeleband, K., \& Hoffman, E. (2006). The influence of different characteristics of the EU environmental management and auditing scheme on technical environmental innovations and economic performance. Ecological Economics, 57(1), 45-59. doi: 10.1016/j.ecolecon.2005.03.013

Rennings, K., \& Zwick, T. (2002). Employment impact of cleaner production on the firm level empirical evidence from a survey in five European countries. International Journal of Innovation Management, 6(3), 319-342. doi: 10.1142/S1363919602000604

Salavou, H., Baltas, G., \& Lioukas, S. (2004). Organizational innovation in SMEs: the importance of strategic orientation and competitive structure. European Journal of Marketing, 38(9), 1091-112. doi: 10.1108/03090560410548889 
Schumpeter, J. A. (1982). Teoria do desenvolvimento econômico: uma investigação sobre lucros, capital, crédito, juro e o ciclo econômico. São Paulo: Abril Cultural.

Serviço Brasileiro de Apoio às Micro e Pequenas Empresas. (2009). Critérios e conceitos para classificação de empresas. Retrieved from http://www.sebraesc.com.br/leis/default.asp?vcdtexto $=4154$

Silva, J. C. G., Filho, \& Sicsu, A. B. (2003). Produção mais limpa: uma ferramenta da gestão ambiental aplicada às empresas nacionais. Anais do Encontro Nacional de Engenharia de Produção, Ouro Preto, MG, Brasil, 23.

Tidd, J., Bessant, J., \& Pavitt, K. (2008). Gestão da inovação (3a ed.). Porto Alegre: Bookman.

Tigre, P. B. (2006). Gestão da inovação: a economia da tecnologia no Brasil. Rio de Janeiro: Elsevier.

World Business Council for Sustainable Development. (2000). Measuring eco-efficiency - a guide to reporting company performance. World Business Council for Sustainable Development, USA. Retrieved from http://www.gdrc.org/sustbiz/measuring.pdf

Zucatto, A., Silva, L. C., \& Pedrozo, E. T. N. (2011). Aspectos ambientais e a concepção de inovações na indústria moveleira. Anais do Encontro Internacional sobre Gestão Empresarial e Meio Ambiente, São Paulo, SP, Brasil, 13.

\section{Authors' Profiles}

Dusan Schreiber

ERS 239, 2755, 93525-075, Novo Hamburgo, RS, Brazil. E-mail address: dusan@feevale.br

Uélinton Telmo Ermel

ERS 239, 2755, 93525-075, Novo Hamburgo, RS, Brazil. E-mail address: uelinton@ feevale.br

João Alcione Sganderla Figueiredo

ERS 239, 2755, 93525-075, Novo Hamburgo, RS, Brazil. E-mail address: sganfigue@ feevale.br

Alexandre Zeni

ERS 239, 2755, 93525-075, Novo Hamburgo, RS, Brazil. E-mail address: zeni@ feevale.br 